REPORTS OF MORPHOLOGY
Official Journal of the Scientific Society of Anatomists,
Histologists, Embryologists and Topographic Anatomists
of Ukraine
journal homepage: https://morphology-journal.com

\title{
Features of longitudinal and transverse body sizes in men with various forms of eczema
}

Dmytrenko S. V. ${ }^{1}$, Al-Omary Ala'a Osama Ahmad', Dzevulska I.V. ${ }^{2}$, Skoruk R.V. ${ }^{1}$, Gunas I.V. ${ }^{1}$

${ }^{1}$ National Pirogov Memorial Medical University, Vinnytsya, Ukraine

${ }^{2}$ Bogomolets National Medical University, Kyiv, Ukraine

\author{
ARTICLE INFO \\ Received: 25 August, 2020 \\ Accepted: 28 September, 2020 \\ UDC: $616.379-$ \\ 008.64:577.112:616.61-07-084
}

\section{CORRESPONDING AUTHOR}

e-mail: svetlana7783@ukr.net Dmytrenko S.V.
Consideration of the aspect of adaptation, in particular morphological, is expedient with obligatory comparison of morphometric indicators in healthy and sick patients and between groups of patients with different degrees of severity of dermatosis. The aim of the study was to investigate the differences between longitudinal and transverse body sizes between healthy and/or patients with eczema men depending on the severity of the dermatosis. Patients with idiopathic $(n=34)$ and microbial $(n=38)$ eczema men of the first mature age underwent an anthropometric examination according to Bunak. The diagnosis of eczema was made according to the nomenclature of ICD-10. As a control from the data bank of the research center of National Pirogov Memorial Medical University, Vinnytsya anthropometric data of 82 practically healthy men of the same age group were selected. Statistical data processing was performed in the license package "Statistica 5.5" using non-parametric methods of evaluation of the obtained results. In healthy men, compared with patients, higher values were found for: the height of the pubic anthropometric point by 3.5-5.7\% and the height of the acetabular anthropometric point by 4.9-7.5\% compared with sick men with idiopathic mild and severe eczema and mild and severe microbial eczema and lower values for: height of the suprathoracic anthropometric point by 1.7-2.6\% for idiopathic eczema of mild, severe course and microbial eczema of mild course; height of the acromial anthropometric point by 1.62.3\% compared with men with idiopathic eczema of mild and severe course; height of the finger anthropometric point by 3.0-5.9\% compared with men with idiopathic eczema of mild and severe course and microbial eczema of mild and severe course. In healthy men, compared with patients, higher values were found: mid-thoracic diameter - by 3.1 $11.1 \%, 5.5-14.4 \%$, transverse lower thoracic diameter - by $8.6-14.1 \%$ and anteriorposterior mid-thoracic diameter - by 10.2-16.6\% and smaller values: width of shoulders by $15.3-21.1 \%$ compared with men with idiopathic eczema of mild and severe course and microbial eczema of mild and severe course. In healthy individuals, the width of the distal epiphysis of the forearm is greater by $3.14 \%$ compared with patients with idiopathic severe eczema and the width of the distal epiphysis of the crus by $3.1 \%$ compared with patients with microbial eczema of mild course; smaller - the width of the distal epiphysis of the shoulder by $3.0 \%$ compared with patients with idiopathic eczema of severe course and the width of the distal epiphysis of the thigh by 5.2-7.6\% compared with patients with idiopathic eczema of mild and severe course and microbial eczema of mild course. In healthy individuals, the values of the size of the pelvis are lower: interspinous distance - by 8.3-11.6\%, intercristal distance - by $8.7-12.5 \%$ and intertrochanteric distance - by $7.7-10.5 \%$ compared with sick men with idiopathic mild and severe eczema and microbial eczema of the mild and severe course. Differences in longitudinal body size in patients with different forms and severity of eczema. When comparing anthropometric indicators between sick men, the following were found: the height of pubic and acetabular anthropometric points in sick men with idiopathic eczema of mild course is higher by $1.8 \%$ and $1.7 \%$, respectively, compared with sick men with microbial eczema of similar severity; shoulder width in patients with idiopathic eczema of mild course is $4.8 \%$ less than in patients with idiopathic eczema of severe course. Thus, men with eczema have a subpathological constitutional type, which is 
characterized by an elongated "cylindrical" torso, shortened lower extremities, as well as more massive distal and less massive proximal epiphyses of the upper and lower extremities.

Keywords: eczema, longitudinal and transverse body sizes, men.

\section{Introduction}

Eczema is a dermatosis that is often registered in the clinical practice of a dermatovenereologist. The disease is characterized by a chronic course with frequent, prolonged relapses, the difficulty of choosing effective treatment measures. Despite the significant amount of work on the study of this disease, eczema remains an urgent medical and social problem, as it is often the cause of disability, reducing the quality of life of patients $[1,6,23]$.

Many researchers $[2,14]$ consider eczema as a disease of multifactorial nature, the morphological manifestations of which are characterized by increased intercellular spaces, and thus the formation of increased permeability of the epidermal barrier to microorganisms, their toxins, development and maintenance of chronic inflammation. In the process of long-term and comprehensive study of various aspects of the pathogenesis of chronic dermatoses, the dominant role of constitutional, metabolic, mental and immunological components have been determined [8, 10].

The study of the relationship between the types of constitution and various diseases creates the preconditions for understanding the peculiarities of their course and risk factors or resistance. It is known that the standard effect causes different adaptive responses in people of different typological categories [9, 20, 22]. However, in clinical medicine, the average approach to the patient is still widely used without taking into account his constitutional affiliation, which significantly reduces the effectiveness of implemented treatment and prevention programs.

Therefore, it is advisable to consider the aspect of adaptation, in particular morphological, with the mandatory comparison of morphometric parameters in healthy and sick patients and between groups of patients with different degrees of severity of dermatosis.

The aim of the study was to examine the differences between longitudinal and transverse body sizes between healthy and/or patients with eczema men depending on the severity of the dermatosis.

\section{Materials and methods}

Men of the first mature age (22-35 years) patients with idiopathic ( $n=34$, including 16 with mild and 18 with severe) and microbial $(n=38$, including 28 with mild and 10 with severe) eczema, who were examined on the basis of the Military Medical Clinical Center of the Central Region and the Department of Skin and Venereal Diseases with a course of postgraduate education of National Pirogov Memorial Medical University, Vinnytsya, conducted an anthropometric survey in accordance with the scheme of V.V. Bunak (longitudinal and transverse body sizes - $\mathrm{cm}$ ) [3].

The diagnosis of eczema was performed according to the nomenclature ICD-10 (https://zakononline.com.ua/ documents/show/116857_531218).

As a control from the data bank of the research center of National Pirogov Memorial Medical University, Vinnytsya anthropometric data of 82 practically healthy men of the same age group were selected.

Statistical data processing was performed in the license package "Statistica 5.5" using non-parametric methods of evaluation of the obtained results. The reliability of the difference between the values between the independent quantitative values was determined using the Mann-Whitney U-test.

\section{Results}

In healthy men, compared with patients, lower values were found for:

height of the thoracic anthropometric point $(143.8 \pm 6.1)$ compared with men suffering from idiopathic eczema of the mild (147.0 $\pm 3.8 ; p<0.05)$, severe course $(147.7 \pm 4.1 ; p<0.01)$ and microbial eczema of the mild (146.3 $\pm 8.0 ; p=0.063)$ course;

the height of the acromial anthropometric point $(146.9 \pm 7.1)$ compared with men with idiopathic eczema of mild $(149.3 \pm 3.4 ; p<0.01)$ and severe course $(150.3 \pm 4.5$; $\mathrm{p}<0.01)$;

height of the finger anthropometric point $(65.85 \pm 4.95)$ compared with men with idiopathic eczema of the mild $(68.56 \pm 3.22 ; p<0.05)$ and severe course $(69.94 \pm 3.08$; $\mathrm{p}<0.001)$ and microbial eczema of the mild $(67.89 \pm 4.02$; $p<0.05)$ and severe course $(69.00 \pm 4.50 ; p=0.052)$;

width of the distal shoulder epiphysis $(6.899 \pm 0.438)$ compared with men with idiopathic severe eczema (7.111 $\pm 0.582 ; p=0.076)$;

width of the distal thigh epiphysis $(8.917 \pm 0.437)$ compared with men with idiopathic eczema of mild $(9.406 \pm 0.733 ; p<0.05)$ and severe course $(9.500 \pm 0.668$; $\mathrm{p}<0.001)$ and microbial eczema of mild course $(9.646 \pm 0.914$; $\mathrm{p}<0.001$ );

mid-thoracic diameter $(28.35 \pm 2.19)$ compared with men with idiopathic eczema of the mild $(31.88 \pm 2.31 ; p<0.001)$ and severe course $(33.39 \pm 2.91 ; p<0.001)$ and microbial eczema of the mild $(32.64 \pm 4.47 ; p<0.001)$ and severe course (33.10 $\pm 6.15 ; p<0.01)$;

transverse lower thoracic diameter $(25.30 \pm 2.26)$ compared with men with idiopathic eczema of the mild $(27.69 \pm 2.12 ; p<0.001)$ and severe course $(29.28 \pm 3.06$; $p<0.001)$ and microbial eczema of the mild $(29.11 \pm 3.62$; $p<0.001)$ and severe course $(29.40 \pm 4.81 ; p<0.01)$;

anterior-posterior mid-thoracic diameter $(19.93 \pm 2.12)$ compared with men with idiopathic eczema of the mild $(22.19 \pm 3.53 ; p<0.01)$ and severe course $(23.44 \pm 3.38$; 
$\mathrm{p}<0.001)$ and microbial eczema of the mild $(23.89 \pm 4.77$; $\mathrm{p}<0.001)$ and severe course $(23.30 \pm 3.68 ; \mathrm{p}<0.01)$;

interspinous distance $(26.33 \pm 1.98)$ compared with men with idiopathic eczema of the mild $(29.00 \pm 1.93 ; p<0.01)$ and severe course $(29.78 \pm 1.86 ; p<0.001)$ and microbial eczema of the mild $(28.89 \pm 2.82 ; p<0.001)$ and severe course $(28.70 \pm 2.54 ; p<0.01)$;

intercristal distance $(29.38 \pm 2.02)$ compared with men with idiopathic eczema of the mild $(32.38 \pm 2.25 ; p<0.01)$ and severe course $(33.56 \pm 2.06 ; p<0.001)$ and microbial eczema of the mild $(32.18 \pm 3.10 ; p<0.001)$ and severe course (32.70 $\pm 2.83 ; p<0.01)$;

intertrochanteric distance $(32.96 \pm 2.10)$ compared with men with idiopathic eczema of the mild $(36.00 \pm 2.00 ; p<0.01)$ and severe course $(36.83 \pm 2.60 ; p<0.001)$ and microbial eczema of the mild $(36.21 \pm 2.81 ; p<0.001)$ and severe course (35.70 $\pm 2.75 ; p<0.01)$.

In healthy men, compared with patients, greater values were found:

height of pubic anthropometric point $(90.57 \pm 5.04)$ compared with men with idiopathic eczema of the mild $(87.53 \pm 2.45 ; p<0.01)$ and severe course $(87.83 \pm 3.68$; $p<0.01)$ and microbial eczema of the mild $(85.95 \pm 3.46$; $p<0.001)$ and severe course $(85.65 \pm 5.86 ; p<0.01)$;

height of the acetabular anthropometric point $(94.04 \pm 5.40)$ compared with men with idiopathic eczema of the mild $(88.94 \pm 2.14 ; \mathrm{p}<0.001)$ and severe course $(89.67 \pm 2.85 ; p<0.001)$ and microbial eczema of the mild $(87.50 \pm 3.88 ; \mathrm{p}<0.001)$ and severe course $(88.30 \pm 6.34$; $\mathrm{p}<0.01$ );

width of the distal epiphysis of the forearm $(5.724 \pm 0.327)$ compared with patients with idiopathic severe eczema (5.550 $\pm 0.333 ; p<0.05)$;

the width of the distal epiphysis of the crus $(7.277 \pm 0.469)$ compared with men with microbial eczema of mild course (6.964 $\pm 0.606 ; p<0.01$ );

shoulder width $(42.02 \pm 2.64)$ compared with men with idiopathic eczema of the mild $(34.69 \pm 2.15 ; p<0.001)$ and severe course $(36.44 \pm 2.06 ; p<0.001)$ and microbial eczema of the mild $(35.46 \pm 2.43 ; p<0.001)$ and severe course $(36.20 \pm 3.55 ; p<0.001)$;

The height of the pubic anthropometric point in sick men with idiopathic eczema of mild course $(87.53 \pm 2.45)$ is greater compared with sick men with microbial eczema of mild course $(85.95 \pm 3.46 ; p<0.05)$.

Shoulder width in patients with idiopathic eczema of mild course $(34.69 \pm 2.15)$ is less compared with patients with idiopathic eczema of severe course $(36.44 \pm 2.06$; $p<0.05)$.

The height of the acetabular anthropometric point in men with idiopathic eczema of mild course $(88.94 \pm 2.14)$ is greater compared with men with microbial eczema of mild course (87.50 $\pm 3.88 ; p=0.077)$.

\section{Discussion}

Traditionally, the basis of individual-typological diagnosis is the morphological criterion in the form of somatotype, considered as the main "informant" about the nature of the human constitution [11, 12]. A certain set of constitutional features allows to state not only the existing, but also to predict the quantitative and qualitative level of adaptive reactions of the organism. According to many authors, constitutional features precede the disease, not its result. One of the absolute signs of markers of hereditary determinism is the longitudinal size of the body, they are usually the basis of the leading types of constitution. The transverse dimensions of the body are not so strictly inherited and are more closely related to sex, age and environmental influences on the body [17, 21].

It is established that the extreme manifestations of stress of the homeostasis system in the process of adaptation - the basis for the development of certain diseases. Thus, in patients with severe and prolonged forms of dermatitis, extreme and subpathological constitutional types are more often identified [13].

We found higher values in healthy men compared to patients: the height of the pubic anthropometric point by $3.5 \%, 3.1 \%, 5.5 \%$ and $5.7 \%$ and the height of the acetabular anthropometric point by $5.7 \%, 4.9 \%, 7.5 \%$ and $6.5 \%$ compared with sick men with idiopathic eczema of mild and severe course and microbial eczema of mild and severe course; and lower values: suprathoracic anthropometric point height by $2.6 \%, 2.6$ and $1.7 \%$ for idiopathic mild eczema, severe eczema and mild microbial eczema; height of acromial anthropometric point by $1.6 \%$ and $2.3 \%$ compared with men with idiopathic eczema of mild and severe course; height of the finger anthropometric point by $4.0 \%, 5.9 \%, 3.0 \%$ and $4.6 \%$ compared with men with idiopathic eczema of mild and severe course and microbial eczema of mild and severe course.

In healthy men, lower values of mid-thoracic diameter (by $11.1 \%, 3.1 \%, 5.5 \%$ and $14.4 \%$ ), transverse lower thoracic diameter (by $8.6 \%, 13.6 \%, 13.1 \%$ and $14.1 \%$ ) and anterior-posterior mid-thoracic diameter (by 10.2\%, 15.1\%, $16.6 \%$ and $14.5 \%$ ) were found and higher values of shoulder width (by $21.1 \%, 15.3 \%, 18.5 \%$ and $16.1 \%$ ) compared with men with idiopathic mild and severe eczema and mild and severe microbial eczema.

The following regularity was established for the width of the epiphyses of the bones: in healthy subjects the value of these dimensions is larger for the more distal, and smaller - for the more proximal segments of the upper and lower extremities. Thus, in healthy individuals the width of the distal epiphysis of the forearm is greater by $3.14 \%$ compared with patients with idiopathic severe eczema and the width of the distal epiphysis of the crus by $3.1 \%$ compared with patients with microbial eczema of mild course; smaller - the width of the distal epiphysis of the shoulder by $3.0 \%$ compared with patients with idiopathic eczema of severe course and the width of the distal epiphysis of the thigh by $5.2 \%, 6.1 \%$ and $7.6 \%$ compared with patients with idiopathic eczema of mild and severe eczema and microbial eczema of mild course. 
The level of physical development of men directly affects the degree of variability of morphometric parameters. It is shown that the wider the shoulders and the narrower pelvis, the more pronounced the signs of andromorphism, and, conversely, the wide pelvis and narrow shoulders indicate gynecomorphism [19].

In healthy individuals, we found lower values of pelvic size: interspinous distance - by $9.2 \%, 11.6 \%, 8.9 \%$ and $8.3 \%$, intercristal distance - by $9.3 \%, 12.5 \%, 8.7 \%$ and $10.2 \%$ and intertrochanteric distance - by $8.4 \%, 10.5 \%$, 9.0\% and $7.7 \%$ compared with men with idiopathic eczema of mild and severe course and microbial eczema of mild and severe course.

Summarizing the differences in longitudinal and transverse body size between healthy and patients with idiopathic and microbial eczema of mild and severe course, we found a subpathological constitutional type, characterized by elongated "cylindrical" torso, shortened lower extremities and smaller masses, as well as more massive distal and less massive proximal epiphysis of upper and lower limbs.

Depending on the type of eczema, the disease has its own characteristics. Microbial eczema usually has clear boundaries, develops in places of injury, in places of fungal development, on the crus in varicose veins. Idiopathic eczema occurs after nervous stress or for no apparent reason. Unlike microbial, idiopathic eczema is always symmetrical, and has foci without clear boundaries. The course of idiopathic eczema is chronic or recurrent [18].

It was found that one or another constitutional type is accompanied by a more frequent occurrence, faster development, more severe course and worse outcome of the corresponding pathology. Even the intensity of the development of only one group of constitutional features reveals certain correlations with the development of certain diseases. Thus, it has been shown that both asthenics and hypersthenics are more likely to develop chronic diseases of the skin and its appendages with a tendency to recur [7].

Makarchuk I.M. $[15,16]$ in young men with acne without taking into account the severity and with mild and moderate severity of the disease found quite similar to our changes in longitudinal and transverse body size. Thus, in patients with acne, the values of the height of the thoracic point, the transverse middle and lower thoracic dimensions, the width of the distal epiphysis of the thigh, and smaller values of the height of the acetabulum and shoulder width are established.

Chaplyk-Chizho I.O. [4, 5] in men with chronic pyoderma of the general group and with an acute course, as well as with deep pyoderma established only greater than in healthy men, the value of the intercristal size of the pelvis; and in

\section{References}

[1] Abuabara, K., Magyari, A., McCulloch, C. E., Linos, E., Margolis, D. J., \& Langan, S. M. (2019). Prevalence of atopic eczema among patients seen in primary care: data from the Health patients of the general group and with chronic pyoderma only a greater height of the acetabulum point.

When comparing anthropometric parameters between sick men, we found only some differences in longitudinal and transverse body size in patients with different forms and severity of eczema. Thus, the height of pubic and acetabular anthropometric points in patients with idiopathic mild eczema is higher by $1.8 \%$ and $1.7 \%$, respectively, compared with patients with microbial eczema of similar severity. Shoulder width in patients with idiopathic eczema of mild course is $4.8 \%$ less than in patients with idiopathic eczema of severe course.

Makarchuk I.M. [15, 16] also found virtually no differences in longitudinal and transverse body size between patients with varying degrees of acne in young men.

Chaplyk-Chizho I.O. [4] in patients with chronic pyoderma in men found lower values of transverse medium and lower thoracic size than in men with acute pyoderma, both in general and separately, when divided into superficial and deep.

Thus, as a result of the work, for the first time differences in longitudinal and transverse dimensions were revealed between healthy and patients with idiopathic and microbial eczema by Ukrainian men of the first mature age and between patients with different forms and degrees of eczema severity.

\section{Conclusions}

1. In men with idiopathic and microbial eczema of mild and severe course a comparative analysis of longitudinal and transverse body size compared to healthy men, the following manifestations of subpathological constitutional types were found: against the background of higher values of the height of the suprathoracic and acromial anthropometric points (by $1.7-2.6 \%$ and 1.6-2.3\%, respectively), lower values of the height of the pubic and acetabular anthropometric points were established (by 3.1$5.7 \%$ and $4.9-7.5 \%$, respectively); against the background of larger values of mid-thoracic, transverse lower thoracic, anterior-posterior mid-thoracic diameters (by 3.1-14.4\%, 8.6$14.1 \%$ and $10.2-16.6 \%$, respectively) and pelvic sizes (by $7.7-12.5 \%$ ) smaller values of shoulder width (by 15.3-21.1\%) were found; against the background of larger values of the width of the distal epiphysis of the shoulder (by $3.0 \%$ only idiopathic severe eczema) and thighs (by 5.2-7.6\%) lower values of the distal epiphysis of the forearm (by $3.14 \%$ only idiopathic eczema of severe course) and crus (by $3.1 \%$ only microbial eczema of mild course) were established.

2. Between patients with idiopathic eczema and/or microbial eczema of varying severity found only a few significant differences in longitudinal and transverse body size.

Improvement Network. Annals of Internal Medicine, 170(5), 354-356. doi: 10.7326/M18-2246

[2] Bin, L., \& Leung, D. Y. (2016). Genetic and epigenetic studies of 
atopic dermatitis. Allergy, Asthma \& Clinical Immunology, 12(1), 1-14. doi: $10.1186 / \mathrm{s} 13223-016-0158-5$

[3] Bunak, V. V. (1941). Anthropometry. M.: People's Commissariat of the RSFSR.

[4] Chaplyk-Chyzho, I. O. (2015). Difference stransversal body sizes between healthy and sick with pyogenic skin infections men and women. Biomedical and Biosocial Anthropology, 25, 85-87.

[5] Chaplyk-Chyzho, I. O. (2015). Features of total, longitudinal body size and width of distal epiphysis of long bones of limbs in healthy and sick with pyogenic skin infections men and women. World of Medicine and Biology, 11, 4-2(54), 79-81.

[6] Drucker, A. M., Wang, A. R., Li, W. Q., Sevetson, E., Block, J. K., \& Qureshi, A. A. (2017). The burden of atopic dermatitis: summary of a report for the National Eczema Association. Journal of Investigative Dermatology, 137(1), 26-30. doi: 10.1016/j.jid.2016.07.012

[7] Ely, H. (1997). Human phenotypes. The atopic and seborrheic: Part II. Cutis (New York, NY), 59(1), 13-18. PMID: 9013065

[8] Eyerich, K., Brown, S. J., White, B. E. P., Tanaka, R. J., Bissonette, R., Dhar, S., ... Reynolds, N. J. (2019). Human and computational models of atopic dermatitis: A review and perspectives by an expert panel of the International Eczema Council. Journal of Allergy and Clinical Immunology, 143(1), 36-45. doi: 10.1016/ j.jaci.2018.10.033

[9] Griffiths, P. E., \& Matthewson, J. (2020). Diseases are Not Adaptations and Neither are Their Causes: A Response to Ardern's "Dysfunction, Disease, and the Limits of Selection" (Biological Theory 13: 4-9, 2018). Biological Theory, 15, 136142. doi: $10.1007 / \mathrm{s} 13752-020-00350-x$

[10] Kaufman, B. P., Guttman-Yassky, E., \& Alexis, A. F. (2018). Atopic dermatitis in diverse racial and ethnic groups - variations in epidemiology, genetics, clinical presentation and treatment. Experimental Dermatology, 27(4), 340-357. doi: 10.1111/ exd. 13514

[11] Klimov, N. lu., Vinnik, lu. lu., Andreichikov, A. V., \& Maksimov, A. S. (2018). Constitutional approach to the study of human diseases at the present stage. Sechenovsky Bulletin, 4, 7077. doi: $10.47093 / 22187332.2018 .4 .70-77$

[12] Koleva, M., Nacheva, A., \& Boev, M. (2002). Somatotype and disease prevalence in adults. Reviews on Environmental Health, 17(1), 65-84. doi: 10.1515/REVEH.2002.17.1.65

[13] Kogan, M. P., Filimonova, E. E., \& Sorokin, E. L. (2019). Types of human constitution and their significance in clinical practice (literature review). Modern Technologies in Ophthalmology, 2, 229-234. doi: 10.25276/2312-4911-2019-2-229-234
[14] Magnifico, I., Petronio Petronio, G., Venditti, N., Cutuli, M. A., Pietrangelo, L., Vergalito, F. ... Di Marco, R. (2020). Atopic dermatitis as a multifactorial skin disorder. Can the analysis of pathophysiological targets represent the winning therapeutic strategy?. Pharmaceuticals, 13(11), 411. doi: 10.3390/ ph13110411

[15] Makarchuk, I. M. (2017). The difference in transverse body size among healthy and acne boys and girls of Podillya, including and without somatotype. Abstracts are presented in the collection of materials of the international scientificpractical conference "Domestic and world medicine in modern conditions", Dnipro (pp. 69-71). Dnipro: Organization of scientific medical research "Salutem".

[16] Makarchuk, I. M. (2014). Differences of total and longitudinal body size between healthy and patients with acne boys and girls with and without the somatotypes. Biomedical and Biosocial Anthropology, 23, 44-48.

[17] Markova, E. V., Fefelova, V. V., Nikolaev, V. G., \& Zakharova, L. B. (1997). Constitutional features of human adaptive capabilities. Topical Issues of Biomedical and Clinical Anthropology, 55-57.

[18] Mulick, A. R., Allen, V., Williams, H. C., Grindlay, D. J., Pearce, N., Abuabara, K., \& Langan, S. M. (2018). Classifying atopic dermatitis: protocol for a systematic review of subtypes (phenotypes) and associated characteristics. BMJ open, 8(9), e023097. doi: 10.1136/bmjopen-2018-023097

[19] Nikitiuk, D. B., Nikolenko, V. N., Khairullin, R. M., Minnibaev, T. Sh., Chava, S. V., \& Alekseeva, N. T. (2013). Anthropometric method and clinical medicine. Journal of Anatomy and Histopathology, 2(2), 10-14.

[20] Nikitiuk, D. B. (2017). The level of functional reserves of the human body and morpho-psycho-functional relationships. Russian Journal of Rehabilitation Medicine, (4), 3-14.

[21] Nikolenko, V. N., Nikitiuk, D. B., \& Klochkova, C. V. (2017). Somatic Constitution and Clinical Medicine. Limited Liability Company Publishing House Practical Medicine.

[22] Svensson, A., Ofenloch, R. F., Bruze, M., Naldi, L., Cazzaniga, S., Elsner, P. ... Diepgen, T. L. (2018). Prevalence of skin disease in a population-based sample of adults from five European countries. British Journal of Dermatology, 178(5), 1111-1118. doi: $10.1111 /$ bjd. 16248

[23] Wootton, C. I., Bell, S., Philavanh, A., Phommachack, K., Soukavong, M., Kidoikhammouan, S. ... Mayxay, M. (2018). Assessing skin disease and associated health-related quality of life in a rural Lao community. BMC Dermatology, 18(1), 110. doi: $10.1186 / \mathrm{s} 12895-018-0079-8$

\section{ОСОБЛИВОСТІ ПОЗДОВЖНІХ І ПОПЕРЕЧНИХ РОЗМІРІВ ТІЛА У ЧОЛОВІКІВ, ХВОРИХ НА РІЗНІ ФОРМИ ЕКЗЕМИ} Дмитренко С.B., Al-Omary Ala'a Osama Ahmad, Дзевульська I.B., Скорук Р.В., Гунас І.В.

Розгляд аспекту адаптації, зокрема морфологічної, $є$ доцільним з обов'язковим порівнянням морфометричних показників у здорових та хворих пацієнтів та між групами пацієнтів з різними ступенями важкості дерматозу. Мета дослідження вивчити відмінності поздовжніх і поперечних розмірів тіла між здоровими та/або хворими на екзему чоловіками в залежності від тяжкості перебігу дерматоза. Хворим на істинну (n=34) та мікробну (n=38) екзему чоловікам першого зрілого віку проведено антропометричне обстеження за Бунаком. Встановлення діагнозу екземи проведено згідно номенклатури MKX-10. В якості контролю з банку даних науково-дослідного центру Вінницького національного медичного університету ім. М.І. Пирогова були відібрані антропометричні дані 82 практично здорових чоловіків аналогічної вікової групи. Статистичну обробку даних проведено в ліцензійному пакеті "Statistica 5.5" із використанням непараметричних методів оцінки отриманих результатів. У здорових чоловіків встановлено більші значення: висоти лобкової антропометричної точки на 3,5-5,7\% та висоти вертлюгової антропометричної точки на 4,9-7,5\% порівняно з хворими чоловіками на істинну екзему легкого $і$ тяжкого перебігу та мікробну екзему легкого і тяжкого перебігу та менші значення: висоти надгруднинної антропометричної точки на 1,7-2,6\%, ніж у чоловіків, хворих на істинну екзему легкого і тяжкого перебігу, а також на мікробну екзему легкого перебігу; висоти акроміальної антропометричної точки на 1,6-2,3\% порівняно з хворими чоловіками на істинну екзему легкого і тяжкого перебігу; висоти пальцевої антропометричної точки на 3,0-5,9\% порівняно з хворими чоловіками на істинну екзему легкого і тяжкого перебігу та мікробну екзему легкого і тяжкого перебігу. У здорових чоловіків встановлено 
більші значення: середньогруднинного діаметра - на 3,1-11,1\%, 5,5-14,4\%, поперечного нижньогруднинного діаметра - на 8,614,1\% і передньо-заднього середньогруднинного діаметра - на 10,2-16,6\% та менші значення: иирини плечей на 15,3-21,1\% порівняно з хворими чоловіками на істинну екзему легкого і тяжкого перебігу та мікробну екзему легкого і тяжкого перебігу. У здорових осіб більші були: ширина дистального епіфіза передпліччя на 3,14\% порівняно з хворими на істинну екзему тяжкого перебігу і ширина дистального епісріза гомілки на 3,1\% порівняно з хворими на мікробну екзему легкого перебігу; менші - ширина дистального епіфріза плеча на 3,0\% порівняно з хворими на істинну екзему тяжкого перебігу і ширина дистального епіріза стегна на 5,2-7,6\% порівняно з хворими чоловіками на істинну екзему легкого і тяжкого перебігу та мікробну екзему легкого перебігу. У здорових осіб менші значення розмірів таза: міжостьової відстані - на 8,3-11,6\%, міжгребеневої відстані - на 8,7-12,5\% і міжвертлюгової відстані - на 7,7-10,5\% порівняно з хворими чоловіками на істинну екзему легкого і тяжкого перебігу та мікробну екзему легкого і тяжкого перебігу. Встановлені відмінності поздовжніх розмірів тіла у хворих з різними фрормами і ступенями важкості екземи. При порівнянні антропометричних показників між хворими чоловіками встановлено: висота лобкової і вертлюгової антропометричних точок у хворих чоловіків на істинну екзему легкого перебігу більша (відповідно) на 1,8\% і 1,7\% порівняно з хворими чоловіками на мікробну екзему аналогічної важкості; иирина плечей у хворих чоловіків на істинну екзему легкого перебігу на 4,8\% менша порівняно з хворими чоловіками на істинну екзему тяжкого перебігу. Таким чином, у хворих на екзему чоловіків встановлений субпатологічний конституціональний тип, який характеризується витягнутим "циліндроподібним" тулубом, укороченими нижніми кінцівками, більш масивними дистальними, а також менш масивними проксимальними епіфрізами верхніх і нижніх кінцівок.

Ключові слова: екзема, поздовжні і поперечні розміри тіла, чоловіки. 